\section{Ethical Lingua}

Journal of Language Teaching and Literature

ISSN 2355-3448 (Print)

ISSN 2540-9190 (Online)

Volume 5, Number 2, August 2018 pp. $123-138$

\title{
Mentor Texts: Models to Improve False Beginners' Writing Skills
}

\author{
Hesthi Herusatoto
}

hesty_h3@yahoo.com

LIA School of Foreign Languages, Yogyakarta, Indonesia

\author{
Received : 11 April 2018; Accepted: 30 July 2018 \\ URL : : http://journal.uncp.ac.id/index.php/ethicallingua/article/view/886 \\ DOI : $\quad$ https://doi.org/10.30605/ethicallingua.v5i2.886
}

\begin{abstract}
This research was to find out the effects of mentor texts on students' ability to write a descriptive paragraph. Changes in the content and organization of their paragraphs were examined closely. As many as 35 students majoring in nursing who were enrolled in an English class participated in this research. In the class, the students learned to write a descriptive paragraph using some mentor texts which served to help them learn identifying and writing a topic sentence, supporting sentences, and a concluding sentence. The texts also provided them with models to make a paragraph have unity and coherence. The data were collected from the student' paragraphs produced before and after the learning process and the paragraph they wrote in the delayed posttest. A survey was also distributed at the end of their English class to collect their responses on the use of mentor texts in their learning process. The findings of this research indicated that mentor texts indeed had positive effects on the students' ability to write a descriptive paragraph. Their awareness to include a topic sentence, details, unity, a concluding sentence, and transition signals in their paragraph was found to significantly develop. In addition, mentor texts enhanced the students' confidence, interest, and motivation in writing.
\end{abstract}

Keywords: mentor text; descriptive paragraph; content and organization 
Herusatoto:

Mentor Texts: Models to Improve False Beginners' Writing Skills

\section{Introduction}

Many EFL students said that writing is difficult. It is because writing requires students to be able to express ideas in a written form with the grammar and vocabulary of the foreign language. As pointed out by Tessema, some reasons that can make writing in a foreign language very difficult are to know the grammar and vocabulary, to present ideas clearly in a good organization, and to have motivation in writing (2005, p. 22). Such reasons often make students lose interest in writing and give up completing writing exercises following the requirements stated by the teacher.

Writing is one of the English language skills difficult to learn by Indonesian students. Even though they have studied English since Junior High School, many of them are unable to use English correctly both in spoken and written forms as they lack practices and exposures to the language. When these Indonesian students pursue an undergraduate degree, non-English departments include English in their curriculum. They, therefore, become false beginners since they "have already studied some English at some point in their life. ...many for a number of years", but they need to study the language again from the beginning (Beare, 2017, p. 1). The reason for some of them might become false beginners is "because of inherent learning problems" of the language (p. 3). Such learners, thus, need other methods with the explicit instruction that can help them learn the target language.

Such kind of false beginners could be found at a Nursing Academy in Yogyakarta. In the third semester, the students majoring in nursing have to take an English subject that required them to be able to write a paragraph in English. A preliminary study using an open-question questionnaire conducted with 35 students at the nursing academy found out several problems that the students had in writing in English. The majority of the students (31 of them or $88.57 \%$ ) mentioned that lack of vocabulary became their major difficulty in writing in English. In addition, 30 of them (85.71\%) said that to make sentences in English was another major problem for them. Using English verb tenses correctly also hampered them to write as stated by 22 of them (62.85\%). It was also found that 6 of them (17.14\%) said that to spell words correctly was difficult for them and 5 of them (14.28\%) felt that writing words in a good order were their problem.

In this research, the researcher attempted to use mentor texts in addition to explicit instruction in teaching writing to the nursing students. The preliminary study had encouraged the researcher to use mentor texts in conjunction with explicit instruction to teach the students to write in English since most of the students still had difficulty to make sentences.

Mentor texts, according to Bartrom, are "any piece of writing that can be used to teach a writer about some aspect of writer's craft" $(2015, p$. 5$)$. She notes that 
in addition to providing a model of a good writing, mentor texts can make students better visualize possibilities for their writing and encourage them "to take risks in their writing and try something new" (2015, p. 5). She further points out that mentor texts "offer instant support to parent educators by providing a framework to follow and structure to lean on" (p. 9). She acknowledges that mentor texts "provide a model of what great writing looks like and encourage students to take risks in their writing and try something new (p. 5)." Students who have no idea of how to write a text with a specific genre, style, or format, thus, can learn and recognize how a text is written with the target genre, style, or format. Students learn by copying someone else's writing. However, copying here does not mean plagiarism. It is thus believed that mentor texts facilitate beginners who are unable to write at basic levels and help advanced students who learn to write various forms and genres of writing.

Research on using mentor texts to improve EFL students' writing has shown positive influences on students' writing knowledge. A study conducted by Turner (2015) investigating the effects of mentor texts and a writing workshop on 12 students' writing abilities revealed that the use of mentor texts in combination with the writing workshop increased not only the students' interest in writing but also their motivation to write (p.4). She used short stories to teach the first-grade elementary students, various punctuations, to show them how to write dialogs in their writing, and to develop ideas. Her four-week-study also found that the mentor texts and the writing workshop developed the students' confidence in their writing abilities as well as developed collaboration among them. Students' awareness of various types of writing techniques and strategies also increased.

That mentor texts have positive effects on students' writing ability is also shown in the results of Abbuhl's study (2011). She conducted a quantitative study with native speakers of English, non-native speakers of English with higher proficiency and non-native speakers of English with lower proficiency. She compared the effects of model texts and model texts combined with explicit instruction on the writing abilities of those three groups of learners. It was reported that the students receiving model texts with explicit instruction performed better in their 3 essays than those only receiving model texts. She further noted that it is not sufficient to use only models, for explicit instruction "facilitate students' noticing and understanding the target rhetorical strategies" ( $p$. 9).

Bashyal (2009), in a study with English trainee teachers at an Educational Training Center in Palpa, Nepal, used a postcard letter as the model text for deconstruction practice to analyze the text's dictions, grammar, organization, and other writing components. He named his teaching writing approach using mentor texts as Model Text Deconstruction Process (MTDP). The trainee teachers acknowledged that they benefited much from the model texts as the text not only 
Herusatoto:

Mentor Texts: Models to Improve False Beginners' Writing Skills

helped them learn the components of writing, possible words, and structure but also developed their confidence. In addition, they considered the technique of teaching writing makes teaching writing easier.

In a study examining the effectiveness of text-based modeling strategy (TBMS) in increasing high school students' competence in writing an essay, Sudaryat (2013) also found that model texts indeed had a positive effect on the students' writing. He claimed that such texts increased the students' competence in five aspects of discourse, namely substantive, textual, lexical, syntactic, and graphemic items. The texts also assisted the students to overcome obstacles to writing an essay.

This research was an action research which attempted to help the nursing students develop their writing ability to write a paragraph in English. They were false learners who needed an additional method that was combined with teacher's explicit instructions to assist them to learn writing in English. Mentor texts were applied in their EFL classroom to identify the effects of the texts on the development of content and organization of their writing. The research questions addressed in this research were: 1) Do mentor texts combined with explicit instruction have effects on the students' ability to write a paragraph? 2) If so, what changes can be seen in the content and organization of their paragraphs? 3) Do the mentor texts assist the students in writing?

This research was thus to examine the effects of mentor texts on the students' ability to write a paragraph and to study the changes or development of content and organization of their paragraphs. The content and organization covered the topic sentence, supporting sentences, unity, coherence, and the concluding sentence of the paragraph. Writing conventions which included punctuation, spelling, and grammar were also studied. This research also tried to find out if mentor texts helped the students to write and to overcome any problems they had when writing.

\section{Method}

This research was classroom action research (CAR) with a pretest and posttest design. CAR was conducted by the teacher in her classroom to improve her teaching. The research took the following steps: identifying problems, planning action, collecting data, analyzing data, and planning for future action.

The subjects of this research were 35 students majoring in nursing who were enrolled at a Nursing Academy in Yogyakarta. They were third-semester students taking English I class which aimed at improving their ability in using English verb tenses in sentences and at developing the students' ability in writing a descriptive paragraph. The students had learned English in their Junior and High Schools. They were false-beginners as they had got a basic knowledge of English, yet they had to study it again like beginners. In the first five meetings of the English I class, 
they reviewed the use of 5 English verb tenses, i.e. Simple Present, Simple Present Continuous, Simple Past, Simple Future, and Present Perfect Tense. The rest six meetings were allocated to study writing a descriptive paragraph in which mentor texts were applied in the teaching-learning process.

To identify the research problems, a preliminary study using an open-question survey to identify the difficulties the students had in writing in English was distributed before the first week of the writing instruction using mentor texts. The answers to the survey were to formulate the research questions.

In the planning action, a pretest and posttest design were prepared for this research. The research took place over a course of eight weeks in a natural classroom setting of English 1 class. During the semester the students had the English I class for 100 minutes a week. In the first week, students were asked to write a descriptive paragraph of their favorite place. The paragraph served as the pretest. They were encouraged to use vocabulary they had known. In the second to fifth week, they learnt to write a paragraph using some mentor texts provided by the teacher which were taken from Blanchard and Root's (2006) Get Ready to Write: A First Composition Text pages 60, 69, and 75, and Oshima and Hogue's (2007) Introduction to Academic Writing page 68. The texts from Blanchard and Root page 60 and Oshima and Hogue page 68 were used as models of getting ideas of what to write in a descriptive paragraph. Blanchard and Root's text page 69 was to practice noticing unity in a paragraph, and the one on page 75 was to practice noticing unity, coherence, and grammar in a paragraph.

The mentor texts were used to learn brainstorming ideas, to identify and write a good and correct topic sentence, supporting sentences, and a concluding sentence of a descriptive paragraph, and to make a paragraph have unity and coherence. In the sixth week, the students wrote a new paragraph, which became the post-test.

A student writing attitude survey was completed in the sixth week after the students wrote a paragraph for the posttest. The survey asked what the students felt when writing, whether mentor texts helped them to write, and any problems that students still had in writing.

In week eighth, students had another test (delayed posttest) which required them to write a descriptive paragraph about their hometown. The test scores were also collected at the research data to provide validity.

Quantitative data collection methods were used to get information for the analysis. The student' writings before and after the intervention (pretest and posttest) and their delayed posttest were assessed using a paragraph rubric designed to see students' improvement in writing a paragraph. The rubric was adapted from the scoring rubrics used by Premont (2016) in his research on 
Herusatoto:

Mentor Texts: Models to Improve False Beginners' Writing Skills

Picture Books as Mentor Texts for $10^{\text {th }}$ Grade Struggling Writers. The assessment focused on the content and organization of their paragraph which covered the topic sentence, supporting sentences, unity, coherence, and the concluding sentence of the paragraph. Writing conventions which included punctuation, spelling, and grammar were also scored using the rubric. Below is the rubric to assess the students' paragraph.

Paragraph rubric

Adapted from Premont (2016, pp. 119-120)

\begin{tabular}{|c|c|c|}
\hline SCORE & ITEM SCORED & DESCRIPTIONS \\
\hline 5 & $\begin{array}{l}\text { Topic sentence } \\
\text { Supporting sentences } \\
\text { Unity } \\
\text { Concluding sentence } \\
\text { Transition signals } \\
\text { Conventions }\end{array}$ & $\begin{array}{l}\text { Topic is clear; controlling ideas are clear. } \\
\text { Give details/examples that explain the topic sentence. } \\
\text { All supporting sentences are on topic. } \\
\text { Restates the main ideas in different words. } \\
\text { Effectively used. } \\
\text { Spelling is mostly correct; punctuation is accurate; } \\
\text { grammar is correct. }\end{array}$ \\
\hline 3 & $\begin{array}{l}\text { Topic sentence } \\
\text { Supporting sentences } \\
\text { Unity } \\
\text { Concluding sentence } \\
\text { Transition signals } \\
\text { Conventions }\end{array}$ & $\begin{array}{l}\text { Not clear; has topic but no controlling ideas or does not } \\
\text { sum up all main ideas of the paragraph. } \\
\text { Do not give adequate details/examples that explain the } \\
\text { topic sentence. } \\
\text { Some supporting sentences are not on topic. } \\
\text { Does not restate the main ideas. } \\
\text { Incorrectly/carelessly used. } \\
\text { Spelling errors on some words; punctuation is mostly } \\
\text { correct; grammar problems are not serious. }\end{array}$ \\
\hline 1 & $\begin{array}{l}\text { Topic sentence } \\
\text { Supporting sentences } \\
\text { Unity } \\
\text { Concluding sentence } \\
\text { Transition signals } \\
\text { Conventions }\end{array}$ & $\begin{array}{l}\text { No topic sentence or only mentions the topic without } \\
\text { controlling ideas. } \\
\text { Supporting sentences ramble, do not connect to each } \\
\text { other at all. } \\
\text { Supporting sentences are not on topic. } \\
\text { No concluding sentence. } \\
\text { No transition signals. } \\
\text { Spelling errors are frequent; punctuation is often } \\
\text { missing; grammar errors are serious. }\end{array}$ \\
\hline
\end{tabular}

Qualitative data collection methods were also employed in this research by distributing a writing attitude survey after the posttest and conducting observations of student attitude while taking the pretest and posttest as well as while they learned using mentor texts in class. These were to get information about whether mentor texts assisted the students to write and to overcome problems they faced when writing. Moreover, observing students' pretest, posttest, and delayed posttest paragraphs was done to see the progress or changes in the students' writing.

Statistical analysis with a paired sample t-test using SPSS was applied to examine the mean difference between the pretest and posttest scores. The delayed posttest was also analyzed and compared to the posttest scores using the paired sample t-test to see the improvement in the content and organization 
of the students' paragraphs. In addition, the average score of each item assessed was examined to look at the improvement in the content and organization of the students' paragraphs.

The results of student writing attitude survey were discussed to see what the students felt when writing after learning using mentor texts and to see if the mentor texts helped them to learn writing.

Observations of student attitude while learning using mentor texts were also used to gather information to support the results of student writing attitude survey.

Planning for future action was then conducted based on the findings of this research. Some other aspects that were not addressed in this present research would be presented.

\section{Results}

\section{Students' pretest, posttest, and delayed posttest scores}

To find out if mentor texts combined with explicit instruction had effects on the students' ability to write, paired-samples tests were employed as they showed significant differences in the scores of pretest, posttest, and delayed posttest.

Table 1. Pretest and Posttest Paired Samples Statistics

\begin{tabular}{cccccc}
\hline & Mean & N & Std. Deviation & $\begin{array}{c}\text { Std. Error } \\
\text { Mean }\end{array}$ \\
\hline Pair 1 & Pretest & 15.83 & 35 & 4.349 & .735 \\
& Posttest & 21.37 & 35 & 6.054 & 1.023 \\
& Delayed & 19.43 & 35 & 5.689 & .962 \\
& & & & \\
\hline
\end{tabular}

The mean score of pretest was 15.83 and that of the posttest was 21.37. The gain score was 5.54 suggesting that the students improved their writing performance on the posttest. The standard deviation of the posttest increased from 4.349 to 6.054 indicating that the students' posttest scores were closer to the posttest mean. The highest score in the pretest was achieved by one student (student 2) with a score of 26, and the lowest score was 6 achieved by 6 students $(8,14$, and 32). More students got a better score in the posttest. Eight (students 1 , $5,11,12,16,19,25$, and 34 ) succeeded to get the highest score of 28 , and two (students 10 and 14) got the lowest score of 8 .

As for the delayed posttest, the mean score was 19.43. The gain score between the pretest and the delayed posttest was 3.6 suggesting that the students also improved their writing performance on the delayed posttest. Only a student (student 19) achieved the highest score of 30 in the delayed posttest; also, only a student (student 14) got the lowest score of 6 . The standard deviation 
Herusatoto:

Mentor Texts: Models to Improve False Beginners' Writing Skills

of the delayed posttest also increased from 4.349 to 5.689 indicating that the students' delayed posttest scores were farther away from the mean (19.43).

As seen in Table 1, however, the posttest showed better mean score than the delayed posttest suggesting that the students' writing performance did not improve on the delayed posttest. The standard deviation of the posttest decreased from 6.054 to 5.689 indicating that the students' delayed posttest scores were closer to the mean (19.43). This reflects a small amount of variation in the scores which is good.

Table 2. Pretest, Posttest, and Delayed Posttest Paired Samples t-test

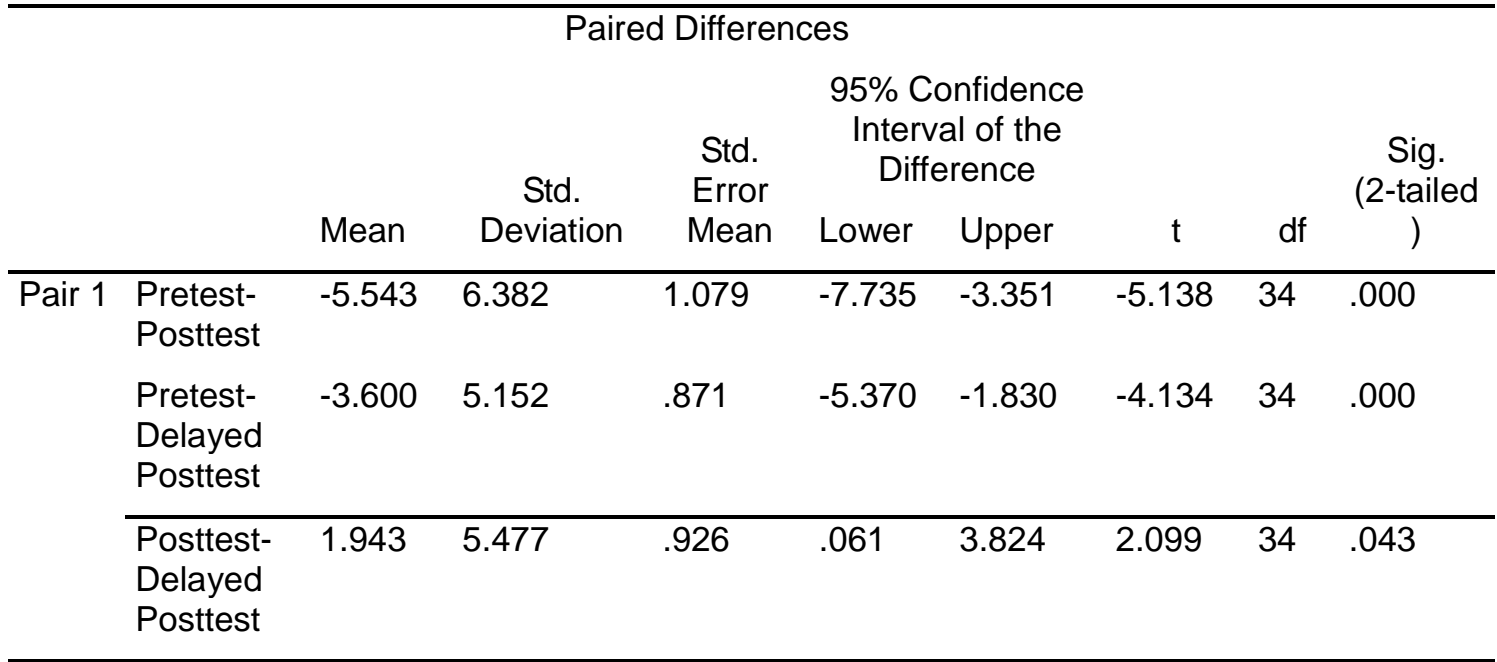

The calculation of pretest-posttest indicates the $p$-value of 0.000 which was smaller than 0.05 . In other words, a significant difference was found in the students' pretest and posttest. The paired-samples t-test on the pretest and delayed posttest also shows that the p-value was 0.000 which was less than 0.05 . It confirmed that the students' writing statistically improved on the delayed posttest. In addition, the result of the paired-samples t-test on the posttest and delayed posttest indicates a p-value of 0.043 which was lower than 0.05 . Thus, there was a significant difference between the posttest and the delayed posttest scores of the students.

The paired samples t-tests revealed that there were significant differences between the pretest and posttest, and between the pretest and delayed posttest with a p-value of $0.000(<0.05)$ respectively. In the posttest, twenty-seven students showed improvement, five (student 2, 10, 22, 26, and 29) decreased their scores, and the rest three students (student 3,6, and 27) achieved the same scores as their pretest. Compared to the delayed posttest, twenty-two students got better scores than their pretest, seven (student 2, 10, 15, 22, 25, 26, and 27) decreased their scores, and six (student 3, 9, 11, 14, 28, and 35) showed the same scores. A significant difference was also found between the posttest and delayed posttest with a p-value of 0.043 . Nevertheless, the posttest mean score 
(21.4) was higher than the delayed posttest (19.4). Only eight students $(6,7,10$, $18,19,23,24$, and 29) improved their scores in the delayed posttest, while twenty of them got lower scores. The rest seven students $(2,3,13,26,30,32$, and 33$)$ received the same scores as their posttest.

\section{Changes in the students' content and organization of their paragraphs}

To examine changes in the students' content and organization of their paragraphs, the average scores of such items as topic sentence, supporting sentences, concluding sentences, unity, the use of transition signals to show coherence and writing conventions were illustrated in Table 3.

Table 3. Students' content and organization

\begin{tabular}{lcccccc}
\hline & $\begin{array}{c}\text { Topic } \\
\text { Sentence }\end{array}$ & $\begin{array}{c}\text { Supporting } \\
\text { Sentences }\end{array}$ & Unity & $\begin{array}{c}\text { Concluding } \\
\text { Sentence }\end{array}$ & $\begin{array}{c}\text { Transition } \\
\text { Signal/ } \\
\text { Coherence }\end{array}$ & Conventions \\
\hline Pretest & 4.31 & 2.60 & 2.83 & 2.26 & 1.00 & 2.77 \\
Posttest & 4.26 & 3.46 & 3.63 & 3.80 & 3.51 & 2.71 \\
Delayed & 3.29 & 3.63 & 3.57 & 3.40 & 3.00 & 2.54 \\
posttest & & & & & & \\
\hline
\end{tabular}

\section{Topic sentence}

The average pretest score (4.31) of the topic sentence was found to be the highest of the three tests given. Twenty-nine of the students wrote a clear topic sentence in their paragraph. They used the topic of the paragraph which was "My favorite place" as part of the topic sentence of their paragraph. They mentioned their favorite place in the first sentence of their paragraph which made their topic sentences had a clear controlling idea. Six students, on the other hand, wrote directly the description of their favorite room which resulted in the absence of a topic sentence.

In the posttest, the paragraphs of 25 students showed a clear topic sentence with the topic of the paragraph mentioned and students' favorite place written as the controlling idea. However, 7 students failed to write a clear topic sentence as they did not indicate the main ideas of the paragraph. They directly wrote the name of their favorite place and told about the place. The rest three students did not write a topic sentence for their paragraph. They failed to show a good topic sentence as they told about a place without giving controlling ideas. Two of them (student 14 and 32) were the same students whose paragraphs in the pretest had no topic sentence.

The average score of topic sentence in the delayed posttest (3.29) was the lowest compared to the other two tests. Only 13 students wrote the topic sentence clearly in their paragraph. Fourteen students either failed to write the 
Herusatoto:

Mentor Texts: Models to Improve False Beginners' Writing Skills

controlling ideas or to include all main ideas of their paragraph in their topic sentence. Eight students had no topic sentence in their paragraphs. Some mentioned too many details which did not contribute to the contents of their paragraph and some did not tell the reader what their paragraph was about, for they jumped to their supporting sentences. Three of those eight students (student 14,15 , and 32) were the same students who did not have a topic sentence in their pretest paragraph.

\section{Supporting Sentences}

Unlike topic sentence, the average scores of supporting sentences show a progress. The highest average score can be seen in the delayed posttest (3.63), in which 15 students explained the topic sentence with explicit details or examples, and 16 did provide details that supported their topic sentence, yet the details were not many. In addition, four students wrote phrases or sentences that did not connect with each other about the topic of the paragraph, and they even wrote some words in Bahasa.

The average score of the posttest (3.46) was also better than that of the pretest (2.60), indicating that students made a progress in the contents of their paragraph. As many as 13 students provided clear details in their paragraph, while 17 lacked details to support their topic sentence. Five students wrote rambling sentences that did not show any details of the topic or topic sentence.

As for the pretest, only one student gave adequate details to her topic sentence, while the supporting sentences of twenty-six students were lack of details. The rest eight students failed to give supporting sentences in their paragraphs. Some only wrote one to two sentences or phrases that did not yet describe the place they were trying to talk about, and others wrote sentences that were disconnected and did not explain the topic.

\section{Unity}

Unity of the students' paragraph was the best achieved in the posttest. As many as 16 students could write supporting sentences that were exactly on topic and 14 had some supporting sentences that were off topic. Five students (student $6,10,14,26$, and 27) whose supporting sentences were rambling got the lowest score of unity for their paragraphs.

The delayed posttest's average score (3.57) was lower than the posttest (3.63). Fourteen students succeeded to provide supporting sentences that did not distract from the topic, while seventeen were found to construct several sentences that did not connect to the topic as they attempted to write more details to explain the topic sentence. Similar to the posttest, four students who failed to provide supporting sentences were not able to demonstrate unity in the content of their paragraphs. Three of those four students (student 14, 26, and 27) were the same students who got the lowest score of unity in their posttest, while the other 
student (student 25) seemed to find difficulty to construct sentences which made her paragraph not have clear supporting sentences.

In the pretest, students did not write many supporting sentences. The pretest average score of unity was the lowest (2.83) as only 6 students were able to write supporting sentences that were on topic. Among the supporting sentences written by twenty students, several sentences were found to be off the topic; and nine students did not show any unity in their supporting sentences, eight of them (student 5, 8, 12, 14, 21, 25, 31, and 32) were those who did not provide supporting sentences that were on topic.

\section{Concluding sentences}

The average score of the concluding sentence was the best in the posttest (3.80). Twenty students were successful to write a concluding sentence for their paragraph that restates their main ideas, and nine had a concluding sentence that did not restate the main ideas of their paragraph. The rest six students did not demonstrate a concluding sentence in their paragraphs. Three of them (student 3 , 6 , and 23) had a clear topic sentence but failed to provide a concluding sentence for their paragraph; one (student 29) whose topic sentences had no specific controlling ideas also missed to write the conclusion; and two (student 10 and 32) did not supply a concluding sentence since they also did not provide a clear topic sentence.

The delayed posttest showed an average score which was below the posttest (3.40). Only 14 students provided a clear concluding sentence, while 14 other students whose most of their topic sentences had no clear controlling ideas made a concluding sentence for their paragraph that did not restate the main ideas of their paragraph. Those who were unable to give a concluding sentence were four students (student 14, 15, 29, and 32) who also did not give a topic sentence for their paragraph, two (student 3 and 10) who wrote a good topic sentence but forgot to write a concluding sentence, and one (student 27) who seemed to have troubles when writing her paragraph.

The majority of the students (22 students) were not able to construct a concluding sentence for their paragraph which made the average score of the concluding paragraph in pretest show the lowest score (2.26). Eight students were successful to write a conclusion restating the topic sentence, while five students provided a conclusion which was not related to the main ideas.

\section{Use of transition signals/coherence}

The ability to link sentences using transition signals which shows paragraph coherence was best seen in the posttest. The average score was 3.51 in which 18 students used transition signals effectively, 8 used them carelessly, and 9 did use any. 
Herusatoto:

Mentor Texts: Models to Improve False Beginners' Writing Skills

However, the number of students who supplied transition signals decreased in the delayed posttest with the average score of 3.00. As many as 15 students effectively show coherence in their paragraph, while transition signals in the other 15 students were absent. The rest 5 students incorrectly used transitions in their paragraphs.

As for the pretest, none of the students were able to demonstrate the use of transition signals which made the average score of this item 1.00.

\section{Conventions}

Conventions which include grammar, punctuations, and spelling reached the highest average score in the pretest (2.77) in which the majority of the students wrote short sentences. Only one student (student 2) got a perfect score for conventions, while most of the students' (29 students) writing showed grammar problems which were not serious. Five students (student 4, 8, 14, 24, and 32) had serious grammar errors as they were not able to supply verbs or use verbs correctly in their sentences.

The average score of conventions decreased a few points in the posttest (2.71). Student 2 still got the perfect score, and 28 students had some errors in their grammar, such as subject-verb agreement and plural forms of nouns, as well as errors in spelling. Six students (student 8, 14, 22, 26, 27, 32), three of them were the same students whose conventions scores were the lowest, showed the inability to write sentences using English sentence patterns.

In the delayed posttest, students tried to write a long paragraph which made as many as 25 students construct sentences with more errors in grammar, but not serious. Nine students (student 8, 11, 14, 21, 25, 26, 27, 32, and 33) displayed serious grammar problems as they could not use verbs correctly in their writing. Only one student (student 19) increased her score of conventions. Even though she wrote a longer paragraph, her sentences were free from serious errors of grammar, spelling, and punctuations.

\section{Student writing attitude survey}

The survey distributed after the posttest helped reveal whether the students benefit from the mentor texts or not. The survey found out that as many as $94.43 \%$ of the students agreed that mentor texts helped them write sentences and organize ideas in their paragraphs. Moreover, $65.71 \%$ of them were more confident and thought that writing was a fun activity for them even though $11.43 \%$ of them acknowledged that they felt confused but curious and motivated when writing. Nevertheless, $60 \%$ of the students said that they still had the minimum vocabulary to write, $48.57 \%$ of them considered it difficult to order words into correct sentences, and $25.71 \%$ had problems to use correct tenses in their sentences. Only $0.57 \%$ viewed that vocabulary was not their main problem anymore when writing. 


\section{Discussion}

Mentor texts with explicit instruction did have positive effects on the students' ability to write a paragraph. Results of the paired samples t-tests indicated a p-value of 0.000 between the pretest and posttest and between the pretest and delayed posttest and a p-value of 0.043 between the posttest and delayed posttest. The majority of the students (77\%) did make a progress in the posttest. This suggested that mentor texts contributed to their learning of writing a paragraph. Many acknowledged that such texts facilitated them to know what sentences to write and how to organize sentences into a paragraph. The mentor texts were used for deconstruction that is to learn the texts' organization, grammar, and other writing components so that what they saw and read in those texts were applied in their writing (Bashyal, 2009).

The mean scores of the three tests given indicated that the posttest was the best. Students made sign of progress in four of the six items scored, namely supporting sentences, unity, concluding the sentence, and transition signals/ coherence. The mean scores for the topic sentence and conventions slightly decreased which might be caused by students' greater attention to complete the other four items. Students tended to write more sentences in their posttest and even much more sentences in their delayed posttest. More than $50 \%$ of the students became aware of writing a concluding sentence to close their paragraphs which were rarely found in their pretest paragraph. Transition signals which were not used at all in their pretest were started to be applied in their posttest paragraph and also in their delayed posttest. Thus, the mentor texts did make them learn to incorporate those items into their paragraphs. The texts successfully encouraged them to use new writing components which made the quality of their writing improve (Abbuhl, 2011).

Even though the mean scores of the six items scored were the best in the posttest, the students' delayed posttest paragraphs were better than their pretest. The same four items were outperformed in the delayed posttests. The mean score for supporting sentences was the best compared to the pretest and posttest since their delayed posttest paragraphs showed that they wrote longer paragraphs with more details in the contents. Their efforts to construct sentences seemed to be getting better as their confidence improved (Bashyal, 2009; Turner, 2015). Nevertheless, it affected their mean score of conventions which became the lowest compared to the pretest and posttest. Grammar was still their main problem in writing. Problems in subject-verb agreement, using singular and plural nouns, supplying the main verb in a sentence were still prominent. The topic sentence also appeared to be neglected as its mean score was also the lowest. Students opted for directly writing the content of their paragraphs which made most of them forget to write the controlling idea in their topic sentence. 
Herusatoto:

Mentor Texts: Models to Improve False Beginners' Writing Skills

The class observation found that many students looked confused and anxious when writing the pretest paragraph and asked the researcher the English words of some Indonesian vocabulary. Even to produce three sentences seemed very difficult for them as they did not what to write or how to write them in English. They were also worried about using incorrect tenses and words in their sentences. Most students only write three to five sentences in the pretest. They struggled so much to construct sentences. In the posttest, on the other hand, most students felt more confident and thought that writing became a fun activity for them. Not only was confidence developed from mentor texts (Bashyal, 2009), but students' interest in writing and motivation to write were also increased with the help of mentor texts (Turner, 2015). Even there were a few students who stated that vocabulary was not a problem for them in writing. It seemed that mentor texts have helped them find words to use in describing a place. That was another result of using mentor texts which were able to provide models for dictions to use in students' writing (Bartrom, 2015; Bashyal, 2009). A few students, however, still asked the English words of some Indonesian vocabulary, while the majority appeared to be busy writing their own paragraphs. It was evident as mentor texts did "encourage students to take risks in their writing and try something new" (Bartrom, 2015, p. 5). Even though the result of student writing attitude survey showed that some students still mentioned that lack of vocabulary, using correct tenses, and ordering words into good sentences hindered them to write, the number of students who addressed those as their problems in writing decreased.

The overall findings above suggest that the students benefited from the mentor texts. The texts served them as models to find ways to write creatively and learn new items to be included in their writings.

\section{Planning for future action}

This research provided information that using mentor texts help students increase their confidence in writing and improve their interest and ability in writing. The mentor text taught them to write a paragraph without forgetting to include a topic sentence, a concluding sentence, unity, and coherence. Additional research can be conducted to see if the students can apply those items in other genres of writing.

Word choice and sentence fluency still seemed to be a problem for the students. Further research, thus, is required to discover if word choice and sentence fluency can also be developed effectively using mentor texts. Students' awareness of writing sentences with correct grammar and words can be examined more. 


\section{Conclusion}

This research found that using mentor texts enhanced high the students' writing ability to write a paragraph. After learning to write using mentor texts, the students were more confident and interested in writing and their motivation to write was also impacted.

In conclusion, this research found that using mentor texts had positive impacts on the students. The mentor texts facilitated the students to learn the content and organization of a descriptive paragraph. The students became more aware of the importance of a topic sentence, details, unity, a concluding sentence, and transition signals in their writing. Providing students with model texts allow them to learn what to include in their paragraph and what to write. This led students to foster their confidence to write and to find writing as a fun activity.

This research suggests that mentor texts can be implemented when giving students explicit instructions to write. The use of mentor texts led the students to discover and notice elements of writing and apply those elements in their writing.

\section{References}

Abbuhl, R. (2011). Using Models in Writing Instruction: A Comparison With Native and Nonnative Speakers of English. SAGE Journals. Retrieved from http://journals.sagepub.com/doi/pdf/10.1177/2158244011426295

Bashyal, G. P. (2009). MTDP: A Model for Teaching Writing. Journal of NELTA, (14) pp. 1-2. Retrieved from http://www.nepjol.info/index.php/ NELTA/article/view/3086/2704

Bartrom, S. (2015). Mentor Texts for Writing Success. Coastal Academy. Retrieved from http://ccis.org/ member-files/spring-

Blanchard, K. \& Root. (2006). Get Ready to Write: A First Composition Text. $2^{\text {nd }}$ Edition. New York: Pearson Education, Inc.,

Beare, K. (2017). Teaching English to Absolute and False Beginners. Retrieved from http://esl.about.com/od/esleflteachingtechnique/a/t afbeginners.htm

Oshima, A. \& Hogue, A. (2007). Introduction to Academic Writing. $3^{\text {rd }}$ Edition. New York: Pearson Education, Inc.

Premon, D.W. (2016). Picture Books as Mentor Texts for $10^{\text {th }}$ Grade Struggling Writers. A thesis. BYU Scholars Archive Citation. Retrieved from https://scholarsarchive.byu.edu/cgi/viewcontent.cgi?article=7368\&context=etd

Sudaryat, Y. (2013). Text-based Modeling Strategy (TBMS) in Teaching Writing Skills. Indonesia University of Education. Retrieved from http://sunda.upi.edu/wp-content/uploads/2013/02/TEXT-BASED-MODELING-STR ATEGY-TBMS-IN-TEACHING-WRITING-SKILLS-.pdf

Turner, K. (2015). The Impact of Using Mentor Texts and the Writing Workshop with First Grade Writers. Department of Language, Literacy, and Special Education College 
Herusatoto:

Mentor Texts: Models to Improve False Beginners' Writing Skills

of Education Rowan University. Thesis. Retrieved from http://rdw.rowan.edu/cgi/viewcontent.cgi?article= 1387\&context=etd

Tessema, K. A. (2005). Stimulating Writing through Project-Based Tasks. English Teaching Forum. Vol. 43, (4), 22-28. Retrieved from

https://americanenglish.state.gov/files/ ae/resource files/05-43-4-d.pdf 